\title{
The Bangladeshi higher education quality assurance framework: a pathway for transformation
}

Naureen Rahnuma

Department of Educational Research

University of Lancaster, UK

Email: n.rahnuma@lancaster.ac.uk

Department of English and Modern Languages

Independent University, Bangladesh

Email: naureen@iub.edu.bd

ORCID: 0000-0002-6283-1972

\begin{abstract}
Bangladesh's approach to devising a Quality Assurance Framework in higher education has eventuated in less than a decade. The framework provides criteria within which universities must operate and encompasses internal self-assessment review and monitoring besides external quality assurance, with the intrinsic goal of operationalising national protocols for a qualification framework. Based on the author's reflection regarding a programme self-assessment exercise as part of internal quality assurance procedure, this paper aims to present an overview of Bangladesh's higher education through contextualisation of the quality assurance initiatives. By analysing the scopes and limitations in the enhancement of quality, this article also proposes how a robust internal quality assurance framework is indispensable to hasten the process of programme accreditation. The article concludes with some recommendations for future revision of Bangladesh's quality assurance system.
\end{abstract}


Keywords: quality assurance framework, enhancement, higher education, internationalisation, accreditation

\section{Introduction}

As one of the world's most densely populated countries, soon-to-be 50 years old, the South Asian nation of Bangladesh is home to more than 162 million people. Named as one of the Next Eleven (N-11) emerging markets by Goldman Sachs, the country has experienced strong and steady gross domestic product growth rates of above six percent in the past few years, most of which is generated by the service sector and manufacturing industries. Bangladesh's leadership has started to view the growing significance of higher education institutions in knowledge production through research and innovation while recognizing the necessity of strengthening its higher education sector to facilitate in creating a knowledgeable and upskilled workforce that will steer the country forward. Indeed, the country has experienced a tremendous surge in demand as the total higher education enrolment over the past decade has surpassed five million students in 2018 (Table 1). Between 2009 and 2018, the number of private universities grew exponentially from 51 to 103 and there was a 30 percent increase as the number of colleges, which increased from 1907 to 2487, particularly in the private sector. By contrast, in the public sector, the number of universities rose from 31 to 42 universities and colleges from 253 to 673 between 2009 and 2018 (Rahnuma, 2020).

Table 1: Number of HEIs and Students, 2018

\begin{tabular}{lcccc}
\hline & Public & Private & $\begin{array}{c}\text { Total } \\
\text { Institutions }\end{array}$ & $\begin{array}{c}\text { Students } \\
\text { (Million) }\end{array}$ \\
\cline { 2 - 5 } Universities & 42 & 103 & 145 & 1.03 \\
Colleges & 116 & 2487 & 2603 & 4.28 \\
Polytechnics & 52 & 387 & 439 & 0.25 \\
\hline Total & 210 & 2977 & 3187 & 5.56 \\
\hline
\end{tabular}

Source: BANBEIS 2018

Such phenomenal increase in student enrolment as well as the proliferation of private higher education institutions to meet that demand over the past decade together have made Bangladesh an example of massification (Ahmed, 2016) of higher education. Massification, according to Trow (2000), is experienced in the last of three different phases of higher education development: elite, mass and universal. Elite represents a national enrolment ratio of up to 15 
percent, while the cut-off point of enrolment rate between mass and universal education is 50 percent. In Bangladesh, massification of higher education has occurred due to improvement in enrolment at both primary and secondary education levels. With gross enrolment ratio at both primary and secondary levels escalating to 116 percent and 72.69 percent respectively in 2018 , according to UNESCO Institute for Statistics, there is a staggering demand from school-leavers seeking access to higher education for greater economic development and empowerment. This increased enrolment has led to democratisation of education and the advent of the knowledge economy which is driven by the social needs of the citizens.

Despite improvements in higher education enrolments, the issue of quality assurance and enhancement has been considered a major strategic tool that impacts on the quality of teaching and learning, research, physical infrastructure and students' overall experiences of learning. These issues were addressed in the government's National Education Policy (2010) and the establishment of a national accreditation council was endorsed by the University Grants Commission (UGC), Bangladesh as part of the Strategic Plan for Higher Education 2006-2026. Initiated in 2009 with financial support of USD 257.11 million from the World Bank, the Higher Education Quality Enhancement Project (HEQEP) has been Bangladesh's toolkit to promote the establishment of a Quality Assurance Framework (QAF) as part of the effort to foster a greater degree of university autonomy and accountability in preparation for an estimated demand of an additional 700,000 students enrolment over the next decade (British Council Report, 2012).

To this end, higher education policy in Bangladesh is currently focused on developing and implementing a quality assurance policy, evolving from relevant educational legislations and directives to pave the way for the formation of a national accreditation body for Bangladeshi higher education institutions. In order to prepare for this, the Ministry of Education has established a Quality Assurance Unit (QAU) as part of the HEQEP project. As a constituent of the project, individual universities are mandated to establish an administrative body of quality management (Institutional Quality Assurance Cells (IQAC) whose prime responsibility is to initiate, develop and administer long-term quality assurance mechanism through a framework to safeguard quality against predefined benchmarks. Many higher education institutions in Bangladesh have duly set up their own internal quality assurance mechanisms operating within 
the QAF as stated in the IQAC operations manual to adhere to a set of specified expectations to safeguard their academic standards while improving student learning opportunities.

With this is mind, the paper aims to critically review literature to elucidate the notion of quality and quality assurance and enhancement in the higher education context. While the paper additionally maps processes of development and management of quality assurance in the transnational context of Europe, United Kingdom, Australia and ASEAN higher education, it also endeavours to situate Bangladesh's reforms of quality assurance in higher education within its scopes and limitations in the process of enhancement of quality.

\section{Higher education in Bangladesh and its challenges: an overview}

A long history of British colonisation and an ensuing Pakistani rule shaped the means of governance in a pathway towards centralisation after Bangladesh's independence in 1971. Particularly in the context of higher education, the central role of the Ministry of Education as an apex policy-making body culminated in the establishment of the main administrative agency namely UGC of Bangladesh, modelled after the defunct University Grants Committee of UK (1919-1989), following a Presidential Order (No. 10 of 1973). With the prime objective of recognition of universities, supervision and maintenance of certain set requirements across publicly funded universities, the UGC Act 1973 defined its agenda of higher education provisions against the wider needs and objectives of the Bangladeshi economy and professional communities as stated under section 5.1(a). Retaining the sole authority to 'evaluate the programmes under implementation for development of (a) university', 'examine all kinds of university development plans' and to 'exercise' powers in conferring 'special degree-awarding status' to higher education institutions, the UGC acted as the national regulator of higher education in Bangladesh.

However, as the social demand for higher education escalated, resulting from domestic socioeconomic factors as well as global trends, the capacity of public higher education institutions was deemed inadequate in meeting the surging demand for higher education. Consequently, the government legislated the privatisation of higher education in 1992 and approved the first private university by means of the promulgation of the Private University Act as a pathway to higher 
education reforms through a shift to neoliberalism in education (Harvey, 2006; Kabir, 2012).

The Act was amended and reamended in 1998 and 2010 respectively to introduce new stipulation based on which private universities could be established and could function, only after being approved by the government on the recommendation of the UGC. Though the private entrepreneurial higher education institutions maintained institutional autonomy with regard to recruitment and remuneration of teachers and staff, means of admission and tuition, their operations were bounded by administrative and financial arrangements predefined by the UGC. Even so, due to shortages of qualified teaching staff, class sizes became several times larger than before, which led to reduced teacher-student interaction with limited scope to adapt teaching according to student needs. Owing to the transformation from an élite to a mass higher education system over the past two decades, in conjunction with rising demands for even larger enrolments (Ahmed, Chowdhury, Rahman \& Talukder, 2014), private institutions were required to make provisions for training skilled workforce for industry and business. Thus, the emergence of private institutions has notably led to the prevalence of market-driven curricula and programmes offering more diverse and job-oriented courses (Alam et al., 2007) such as, pharmaceutical sciences, public health, media studies, global studies and governance, textile engineering, fashion design, merchandising, tourism and hospitality management and sustainable development degrees that emphasize ecology, natural resource management and environmental science and policy through understanding of population, reproductive health, environmental science and management and gender and development.

Yet, many private higher education institutions have failed to meet minimum quality requirements with regards to functioning under an internal governance framework of academic oligarchy, particularly lacking in state-of-the-art teaching facilities besides physical infrastructure essential for setting up libraries, laboratories, research facilities, virtual learning systems, learning zones, study spaces, sports zone and open spaces that promote a sense of community. While further debate also revolves around the issue as to how many Bangladeshi private universities have commodified their services by setting high tuition fees with less focus on quality education, research and innovation, the revised Private University Act (2010) alone could no longer ensure and maintain quality without a formal, institutionalised QAF. Thus, as a part of higher education policy reforms, it was imperative to enact enhancement and 
accreditation mechanisms to strengthen governance as well as enhance accountability for the performance of every higher education institution, both private and state owned, while improving the quality of teaching and research.

\section{Quality assurance in higher education}

As the demand for quality education increases in an extremely competitive world, quality assurance is the key to effective education in the case of higher education institutions where there is increased mobility of students, teaching staff, programmes particularly in global networks (Hou, 2012). Quality assurance and enhancement of a country's higher education is not only key to its social and economic wellbeing, it is also a determining factor affecting the status at the international level (UNESCO, 2005). Indeed, enhancement of quality in higher education has become one of the most prominent conceptualisations of internationalisation in higher education (Maringe, 2010). Yet, ensuring that the quality of programmes meet local and international standards has become a major challenge in many countries (OECD \& World Bank, 2007), especially in South Asia. To address this, a common framework for a quality assurance model could provide consistent assessment of learning design, content and pedagogy.

Even though the concept of quality emerged in higher education in the early 1980s 'from its more familiar industrial and commercial settings' (Newton, 2002, p. 45), it eventually came to be seen, by some, as something that could be defined and measured (Perry, 1991). As a relative concept, quality has several dimensions (Table 2) and is conceptualised according to the circumstances in which it is invoked and means different things to different people (Harvey \& Green, 1993). Each stakeholder in higher education, ranging from students, teaching and nonteaching staff, employers, government and its funding agencies, accreditors, validators, auditors, and assessors (Burrows \& Harvey, 1992), have a different perspective on quality. The privatisation of higher education over time has led to the proliferation of different instruments for the evaluation of quality which influence institutions on how quality is controlled in their provision of education services (Harvey, 2002; Harvey \& Stensaker, 2008). 
Table 2. Definitions of quality in higher education

\begin{tabular}{|l|l|}
\hline Quality & Definition \\
\hline Exceptional & $\begin{array}{l}\text { A traditional concept linked to the idea of 'excellence', usually } \\
\text { operationalised as exceptionally high standards of academic } \\
\text { achievement. Quality is achieved if the standards are surpassed. }\end{array}$ \\
\hline Perfection or consistency & $\begin{array}{l}\text { Focuses on process and sets specifications that it aims to meet. } \\
\text { Quality in this sense is summed up by the interrelated ideas of } \\
\text { zero defects and getting things right first time. }\end{array}$ \\
\hline Fitness for purpose & $\begin{array}{l}\text { Judges quality in terms of the extent to which a product or } \\
\text { service meets its stated purpose. The purpose may be customer- } \\
\text { defined to meet requirements or (in education) institution- } \\
\text { defined to reflect instituional mission (or course objectives). }\end{array}$ \\
\hline Value for money & $\begin{array}{l}\text { Assesses quality in terms of return on investment or } \\
\text { expenditure. At the heart of the value-for-money approach in } \\
\text { education is the notion of accountability. Public services, } \\
\text { including education, are expected to be accountable to the } \\
\text { funders. Increasingly, students are also considering their own } \\
\text { investment in higher education in value-for-money terms. }\end{array}$ \\
\hline Transformation & $\begin{array}{l}\text { Sees quality as a process of change, which in higher education } \\
\text { adds value to students through their learning experience. } \\
\text { Education is not a service for a customer but an ongoing } \\
\text { process of transformation of the participant. This leads to two } \\
\text { notions of transformative quality in education: enhancing the } \\
\text { consumer and empowering the consumer. }\end{array}$ \\
\hline
\end{tabular}

Source: Harvey, 1995

Although different in approaches, quality assurance in higher education is practiced throughout the world with the aim to assure and safeguard academic quality and standards of learning opportunities besides promoting systematic as well as continuous enhancement while ensuring that information about programmes are accessible and fit for all purpose. Best practices for quality assurance require a clearly defined and transparent code of practice on criteria that serve as reference points for evaluations and reports of programmes offered by higher education institutions. Furthermore, university leadership incorporating quality assurance mechanisms must consider 'multiplicity of instruments' and 'channels of accountability' including):

the extent to which access is offered evenly to all groups in society (equity), the standards of teaching and research (quality), the degree to which graduates receive an education matching labour market needs (relevance), the contribution of the university to local and/or national economic development (sometimes called the "third mission"), the values imparted by tertiary education institutions (citizenship and nation-building), the manner in 
which public resources are utilized (internal efficiency) and the financial capacity of the tertiary education system to grow and maintain high standards at the same time (sustainability). (Salmi 2008, p. 7)

Even though the enhancement of quality has been mandated and institutionalised across nations to improve and standardise organisational performances (Koch \& Fisher, 1998), the enactment of a variety of systematic QAFs serves as clear points of reference and can consolidate the implementation process for countries preparing to create a framework. For instance, the standards and parameters set as components of the internal quality assurance in the European Higher Education Area, stated in the European Standards and Guidelines (ENQA, 2015), outline a set of ten key specifications with regards to quality assurance as part of regional initiatives. In the same way, the quality assurance framework of Association of Southeast Asian Nations (ASEAN) University Network delineates an array of categories and sub-categories that set the benchmarks of quality education amongst the ASEAN nations (AUNQA, 2011). Further, the Tertiary Education Quality and Standards Agency in Australia pinpoints a definitive set of threshold standards and processes required to be fulfilled by every Australian higher education institution (TEQSA, 2015). Likewise, the United Kingdom Quality Code provides a narrative of reference points for effective quality assurance through succinctly stated expectations, codes of practices as well as advice and guidance to help higher education institutions to develop and maintain effective quality assurance practices (QAA, 2012). Given such contexts to various nations' procedures and policies of assuring and enhancing quality as manifested in their QAF, the government of Bangladesh has finally established the framework to ensure that Bangladeshi higher education institutions adhere to clearly set guidelines. These quality assurance and enhancement processes enable the improvement of the quality of institutions and present them with opportunities for continuous improvement within a common framework for quality assurance systems at national and institutional level thus promoting accountability as well as recognition across international borders.

\section{Critical analysis of quality assurance in Bangladeshi higher education}

Bangladesh's quality assurance system is in the process of being implemented across every higher education institution through the establishment of IQAC guided by the QAU. The QAU 
supports institutional training of academic as well as administrative staff to build, monitor and evaluate capacity for quality assurance and enhancement in each higher education institutions. While the Bangladesh Accreditation Council Act 2017 has been passed by the Parliament on 7 March 2017, the QAU is still responsible for carrying out capacity building activities and setting relevant quality assurance mechanisms for institutions until the full operationalisation of the accreditation council. IQACs has been founded as a permanent entity in a total of 69 universities (World Bank, 2017) as commencement of an internal quality assurance system in every higher education institution. By establishing and fostering a quality learning and teaching environment congruent with international standards of quality assurance criteria and practices as pointed out in the IQAC Operations Manual, the central mission of IQAC has been to promote and safeguard inclusiveness, transparency and accountability among academicians, administrations and students as part of a sustainable mechanism of quality assurance and enhancement. Simultaneously, through establishing an effective evaluative framework that provide clear evidence of the efficacy and impact of a higher education institution's teaching, learning and assessment policies, IQAC has laid the groundwork for every participating higher education institution to ruminate on its performances while learning how to better manage and deliver its programmes and services through a self-assessment exercise that involve all the stakeholders.

As part of the exercise, a committee is formed in every department or entity of a participating higher education institution in order to self-apprise the existing programme of study against set quality criterion and performance indicators. The quality assurance procedures involve undertaking rigorous internal and external exercises of collecting, generating and analysing data through a range of survey tools, SWOT analysis and final preparation of the report required to be peer reviewed by a panel of external quality assurance experts before a site visit. Interviews with relevant stakeholders and other supporting documentation submitted for scrutiny is utilised to validate the information presented in the review to be a true reflection of current practices. The team of the external quality assurance experts evaluate the strengths and weaknesses in programmes, physical facilities and overall quality of education provision using a five-point rating scale that ranges from unsatisfactory to excellent. An exit report reveals the grade awarded to the entity by the assessors. A detailed external peer review and validation of self-assessment report is sent to the higher education institution providing recommendations and guidance to help 
determine the post self-assessment improvement plan of the entity. Seven hundred and ninety-six such reports had been finalised by December 2018 when HEQEP's first phase of quality assurance officially came to an end (Rahnuma, 2020).

However, the QAF is only designed to provide standard specifications, not so much as a detailed guidance with clear benchmarks and indicators set for academic and administrative activities of Bangladeshi higher education institutions. The quality assurance benchmarks and regulatory mechanisms deemed as critical enablers in developing the quality assurance culture are designed around five key domains (Figure 1): governance and university autonomy, teaching, learning and assessment strategy, student selection and support services, teaching staff and research and extension as part of capacity building. Overall, the criteria for quality assurance in Bangladeshi higher education has been legislated to work both at the institutional as well as programme level. As a higher education institution is primarily responsible for its academic standards and the quality of student learning experience, such institutionalisation of quality assurance enhances sustainable capacity building and strengthens a university's accountability and commitment to the establishment and maintenance of quality assurance infrastructure. Quality assurance at programme level sets out benchmarks to revalidate academic programmes to be fit-for-purpose and provides mechanisms for continuous improvement in both process and quality, to make programmes viable for meeting global standards. 
Internal Quality Assurance
External Quality Assurance
Accreditation

\section{Developing the criteria for $\mathbf{Q A}$ : \\ Governance \\ Curriculum Content, Design \& \\ Review}

Student Entry qualifications, Admission procedure, Progress and Achievements

Physical Facilities

Teaching, Learning and Assessment

Student Support Services

Staff and Facilities

Research and Extension

Process Management \& Continuous Improvement

\section{External peer review by QA} agencies to:

Identify the strength/weaknesses in

QA practices

Develop a working plan to improve the QA practices

Safeguard the quality of delivery of academics

Share good practices in the provision of education
Recognition of QA practices by external quality assurance agencies in accordance to international standard

Gain accreditation from certified agencies

Developing national Quality Assurance and Accreditation Council Bangladesh (ACB) to maintain and enhance quality

\section{Figure 1: The Bangladeshi Higher Education Quality Assurance Framework}

Adapted from Institutional Quality Assurance Cell Operations Manual

\section{Bangladesh's road to quality assurance: current challenges and way forward}

Bangladesh's current QAF has been instrumental in building a quality culture (Rahnuma, 2020) among higher education institutions. Yet, there are some key deficiencies in the framework which may be considered while revising the QAF:

\section{Internationalisation of Bangladesh's higher education}

Since quality assurance mechanism in Bangladesh have been designed and initiated by governmental institutions as in many other Southeast Asian countries, there are concerns about how truly 'independent, transparent and robust' (Dill, 2011) the Bangladeshi quality assurance process is. As Bangladesh stands on the pathway to higher education reforms by choosing to 
begin with an overhaul of both national and institutional higher education infrastructure, a vital undertaking is to assure quality while continuously improving the performances of higher education institutions to gain the confidence of both local and international community through graduate employability and transnational accreditation. When the initial phase of quality assurance eases out, many Bangladeshi higher education institutions, in their response to 'glonacal' trends (Marginson \& Rhoades, 2002), would seek international recognition rather than national and local accreditations to enhance academic competitiveness globally (Deem et al., 2008) while increasing reputation to safeguard enrolment (Hou et al., 2014) just as in countries such as Singapore, South Korea and Taiwan. However, the next challenge is international capacity building of national accreditation, the Bangladesh Accreditation Council, as it begins functioning. As internationalisation of Bangladesh's higher education is seldom possible without cross-border evaluation of academic programmes, the council must strengthen its global, as well as regional, capacity by becoming associated with the International Network of Quality Assurance Agencies in Higher Education and Asian Pacific Quality Network while reinforcing its 'accountability of accreditation' (Eaton, 2011).

\section{Code of practice}

Whilst the national focus has shifted to developing Bangladesh's higher education, it is imperative to reform institutional higher education infrastructure in the implementation phase of the quality assurance and enhancement policy, particularly to develop academic standards in a 'glonacal' era. Reforms to be introduced ought to include revising the national QAF into a code of practice as an outline guidance for the assurance of academic quality and standards in higher education. The code of practice, classifying and identifying a comprehensive series of key expectations with regards to quality assurance and enhancement, could provide an authoritative reference point for higher education institutions to emulate or adapt according to their own needs. Since programmes in Bangladeshi institutions have begun to be audited for the first time, the QAU would need to review the extent to which individual institutions meet the expectations of adhering to threshold standards. Even though criteria of internal institutionalised quality assurance systems and approaches differ across nations due to their traditions, the Bangladeshi

QAF depicts the generic criteria of governance, teaching and learning strategies, programme and curriculum design, student support and staff and physical facilities. 
However, in contrast with international standards and norms, the Bangladeshi institutionalised quality assurance process is yet to evolve as a robust system as it must incorporate clear codes of practices with regards to ongoing academic programme reviews, reviews of faculty or school, staff and student satisfaction, student admission, progression and recognition, mapping of graduate attributes in curriculum, use of key performance indicators in improving quality, reward management system and public access to information. The framework should set clear guidelines for ongoing review of existing programmes periodically on a small sample of student outcomes to measure teaching and learning effectiveness and transparent use of learning outcomes assessment that are standard for a peer set of programmes. It must be legislated that such reports on planning and effectiveness of core educational processes be made public, accessible and comprehensible to both students and their parents. Moreover, as staff development is key to an effective quality culture, there should be clear policy technologies delineating arrangements for staff engagement for developing skills, meeting research strategy and promoting commitment while bridging any implementation gap in the QAF for an effective evaluation system. Additionally, a robust evaluation system, developed through self-assessment and external monitoring, must carry out systematic and periodic reviews to assess staff research productivity, student-staff ratio besides helping the higher education institutions to improve learning outcomes and educational activities.

By means of developing a code of practice on criteria and standards for higher education, the QAF will ultimately steer Bangladeshi higher education institutions to move towards complete autonomy on matters of academia while expanding partnership with industries and international partners in improving the quality of teaching and innovation appropriate to the requirements of the labour market, creating more flexible ways to study, including distance, modular or part-time learning.

\section{Improvement cycle of quality assurance}

A compliance quality assurance system, wherein universities are encouraged to undertake selfassessment, undergo external peer review, improvement efforts and follow-up measures, enable higher education institutions to pinpoint the areas that need improvement. An external quality 
audit provides extrinsic motivation for a higher education institution to document, critique and enhance its internal infrastructure and capabilities for continuous quality assurance and enhancement (Scott, 2003). Such an improvement-led framework of quality assurance system is deemed to be more effective in engaging academics in quality and improvement (Shah \& Jarzabkowski, 2013; Laughton, 2003). However, the real challenge is to monitor the extent to which all the recommendations and guidance, provided by external evaluators, had been implemented within the stipulated timetable. It is important that the UGC stipulates every external peer review report to be made public and digitised to be available online, especially to prospective students and their parents, while helping disseminate good practices to all Bangladeshi higher education institutions to encourage quality enhancement. Therefore, institutions scoring 'excellent' need to be recognised and rewarded with increased government and research funding, while being listed in the top 20 university league table in Bangladesh. Institutions receiving an unsatisfactory rating, would be required to reassess their programmes within a timeframe of four years, which would inevitably impact their ranking in the national league table leading to enrollment drops and even closures. In essence, while Bangladesh completed the first phase of quality assurance, the next phase of the cycle of monitoring and evaluation of enhancement ought to be hardwired into the regulatory framework of the quality cycle itself.

Indeed, broad outcomes and quality process indicators are assessed through internal institutional assessment besides an external review by professional evaluators who produce a report to help institutions identify areas for improvement and prompt action plans accordingly for implementation of recommendations on a cycle of five years. Yet, the onus is on higher education institutions to employ integrated quality assurance by building a quality system that allows them to continuously monitor, ensure and improve the quality of their programmes in order to fulfil the criteria for accreditation. While being compliant with various laws, regulations and reference points as that of the QAF, Bangladeshi higher education institutions must entrench a quality cycle within their strategic plan, thus being able to continuously improve the quality of their provision through an Approach-Deploy-Result-Improve (ADRI) cycle (see Figure 2). As a variant of the Plan-Do-Study-Act cycle made popular by Deming (1993), the ADRI approach has been used to improve quality in a cyclical manner at many universities (Broatch, 2007). In the 
context of continuous improvement, for example, Bangladeshi universities can use the ADRI approach to assess their performance against the visions and goals identified in the strategic plan over a period of five years. The deploy dimension considers how the implementation process is being put into effect by making use of the available resources. In the evaluation phase, the results ought to link back to preconceived goals while determining the best practices and benchmarks. The improvement dimension reviews the results and uses that evidence to review whether the approach and deployment are effective in achieving the intended outputs.
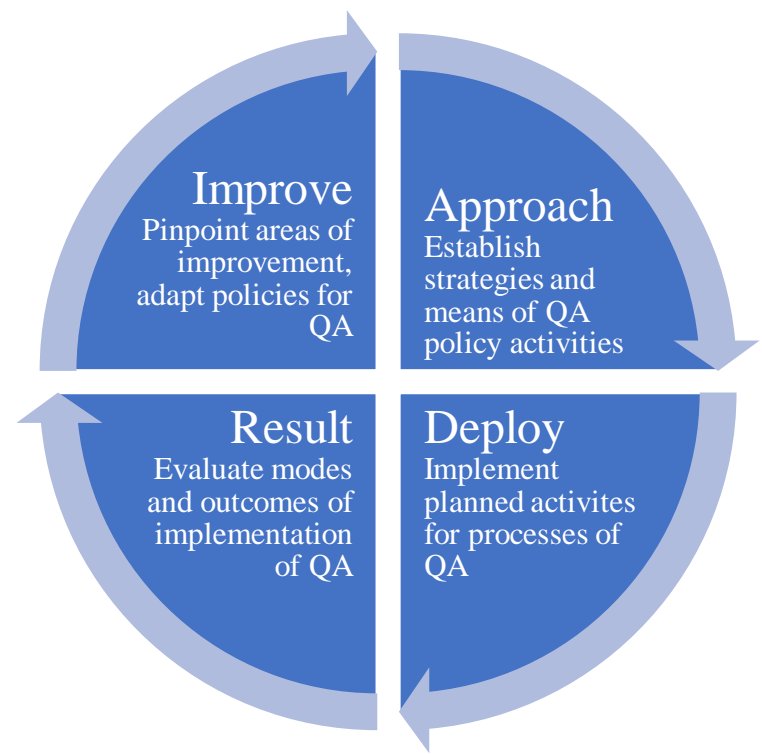

Figure 2: The ADRI Quality Cycle

Adapted from Iqbal and Harsh, 2013

ADRI has been used by many universities as a method for analysing a total quality assurance system as it can help pinpoint strengths as well as opportunities for improvement. ADRI has been used by the Australian Universities Quality Agency in its fitness for purpose quality audits of Australian universities for many years. Self-assessment exercises using ADRI encourages organisations to highlight and record their strengths as well as highlight opportunities for improvement. As a flexible tool, ADRI, in principle, supports a continuous improvement philosophy through an interminable cycle of planning, implementation, review and improvement (Razvi et al, 2012). Such integration of straightforward and coherent quality exercises is key in eliminating ambiguities while promoting staff awareness of the rules and 
principles embedded in the internal quality assurance system, consistent with the needs of stakeholders.

\section{Student engagement and student surveys}

As students are the most important stakeholders, their satisfaction, experiences and expectations must be considered in the management of higher education in a university. The emphasis in quality assurance systems, having gradually shifted from only governance of higher education to human factors (Neave, 1997), is galvanised with equal involvement and ownership of student as well as staff (Brennan \& Shah, 2000). Lack of dialogue and consultation among students, higher education institutions and quality assurance agencies in shaping the quality assurance processes can lead to a lack of effectiveness in the quality assurance process itself. Through effective student engagement, higher education institutions can improve the quality and efficacy of their course design, teaching strategies and assessment practices to produce more meaningful outcomes for students. Prospective students need clear information about what to expect from higher education on such areas as contact with tutors, availability of independent learning resources, digital, language and writing support and feedback on work. There is a tendency for higher education institutions to view students as consumers rather than partners in a learning community. And student involvement in quality processes should start from the idea of building learning communities which 'involves shaping student expectations of their role as responsible partners who are able to take ownership of quality enhancement with staff and engage with them in dialogue about improving assessment, curriculum and teaching' (Ramsden, 2008, p. 6). Even though a mandatory teaching staff evaluation is in place in most of the Bangladeshi private higher education institutions, it is now crucial to incorporate quality measures stipulating all universities to collect detailed feedback of undergraduate as well as postgraduate students about their overall experiences on their programme of study. Thus, the next way forward for quality assurance and enhancement is the formation of student forums to effectively engage with students in higher education institutions so as to collect, analyse and present student satisfaction data and academic subject information in order to benchmark institutional performance data.

These publicly available student satisfaction results, in relation to academic subject information, could help prospective students make informed decisions about choosing where to study while 
providing higher education institutions with a sense of direction towards developing an even better student experience for all.

Since Bangladeshi higher education institutions are faced with increased external pressures and levels of accountability owing to massification of higher education, a university's presence in league tables and its rankings in newspapers and other media will increasingly attract national as well as international candidates and their parents. As very negligible number of Bangladeshi higher education providers make it to the global ranking and league tables, these higher education institutions must do their best to improve their international standing through strategic review, market branding, good governance, facilities and infrastructure improvement, stronger online presence, implementation management, internal and external communications besides accreditation, quality assurance and audit support.

\section{Conclusion}

This article has provided an overview of the regulatory principles that have guided the Bangladeshi QAF and argues the need for higher education institutions to build internal capacity for quality assurance that engages students as well as staff. Since the inception of the QAF, Bangladesh is making its effort in initiating a transition in the way lessons are delivered and student learning outcomes (Bresciani, 2006) are assessed from a student-centered learning and teaching perspective rather than the traditional teacher-oriented one. Under such contexts, as the quality framework undergoes developments and revisions owing to programme as well as institutional evaluation, accreditation or audits, policymakers would need to be apprised of the changing trends in higher education and consider how quality assurance could be used to support them. Just as Bangladesh continues to further strengthen its quality assurance practices, policymakers and stakeholders would need to be convinced that it is necessary to attain some international convergence following generic international quality guidance and practices developed by international or supra-national bodies such as the United Nations Educational, Scientific and Cultural Organisation, the World Bank or the Organisation for Economic Cooperation and Development to remain connected and current in education trends (CHEA, 2014). Quality assurance processes are indeed non-static and often nations manifest a proselytising tendency of cut-and-paste quality assurance policy-making, leading to tightening standards 
(Sursock, 2012), which work alongside quality assurance processes to greatly impact on higher education institutions seeking accreditation. Notably, accreditation confirms a higher education provider's reputation as a quality provider of a particular programme responsive to industry needs and in line with shared practices in a global academic community, thus supporting and signposting graduate employability.

However, as the framework is still not comprehensive in nature with transparent information on procedures of quality assurance arrangements, accreditations and recognition of qualifications, efforts are needed for further international as well as regional networking and collaboration that can help a developing nation like Bangladesh set benchmarks and clear subject specifications towards a more systematic qualification framework, comparable at a global level while promoting increased cross-border mobility of students as well as academic staff and professionals (UNESCO, 2005). As part of an ensemble of generic quality assurance policy technologies, recent reforms in Bangladesh's higher education are only a stepping-stone towards gaining confidence of the stakeholders in the globalised setting by ensuring best practices with transparency, accountability and credibility in accordance with internationally acceptable practices. Therefore, as higher education institutions and their stakeholders approach the quality assurance and accreditation process as opportunities for learning and capacity building rather than an act of compliance, institutions can eventually become self-regulators. With robust and sustainable quality assurance mechanisms in place, Bangladeshi higher education institutions would eventually move toward internationalisation and a greater mobility of students as they create networks, opportunities for exchange and partnership in Asia and beyond

\section{References}

Ahmed, J.U., 2016, 'Massification to marketisation of higher education: private university education in Bangladesh', Higher Education for the Future, 3(1), pp. 76-92.

Ahmed, J.U., Chowdhury, M.H.K., Rahman, S. \& Talukder, A. K. M. M. H. 2014, Academic probation: an empirical study of private university students', Research in Education, 92(2), pp. $1-17$. 
Alam, M., Haque, M.S. \& Siddique, S.F., 2007, 'Private higher education in Bangladesh', in Varghese, N.V., (Ed.), 2007, Research Papers International Institute for Educational Planning, pp. 11 (Bangladesh: International Institute for Educational Planning, UNESCO). Available at https://unesdoc.unesco.org/ark:/48223/pf0000150151(Accessed 2 February 2020)

ASEAN University Network Quality Assurance (AUNQA), 2011, Guide to AUN Actual Quality Assessment at Programme Level. Available at http://www.aunsec.org/pdf/aunwebsite/03_GuidetoAUNActualQualityAssessmentatProgramme Level30March2011PrintVersion.pdf (Accessed 2 February 2020).

Bangladesh Bureau of Educational Information and Statistics (BANBEIS), 2018, 'The educational structure of Bangladesh'. Available at www.moedu.gov.bd (Accessed 28 May 28, 2018).

Brennan, J. \& Shah, T., 2000, Managing Quality in Higher Education: An international perspective on institutional assessment and change (Buckingham: Organization for Economic Cooperation and Development, Society for Research into Higher Education \& Open University Press).

Bresciani, M.J., 2006, Outcomes-Based Academic and Co-Curricular Program Review: A compilation of institutional good practices (Sterling, VA: Stylus Publishing).

British Council, 2012, The Shape of Things to Come: Higher education global trends and emerging opportunities to 2020. Available at https://www.britishcouncil.org/sites/default/files/the_shape_of_things_to_come_-

higher education global trends and emerging opportunities to 2020.pdf (accessed 1 Feb 2020).

Broatch, A., 2007, 'A Brief Guide to the (O) ADRI Cycle. Available at https://www.utas.edu.au/curriculum-and-quality/documents/quality/A-brief-guide-to-OADRI.pdf (Accessed 3 February 2020).

Burrows, A. \& Harvey, L., 1992, 'Defining quality in higher education: the stakeholder approach', paper to the AETT conference on 'Quality in Education', University of York, 6-8 April 1992.

Council for Higher Education Accreditation (CHE), 2014, International Higher Education and International Quality Standards. Policy Brief No. 3. Available at https://www.chea.org/userfiles/Policy-Briefs/CIQG_Policy_Brief_Vol-3.pdf (Accessed 12 June 2018).

Deem, R., Mok, K.H. \& Lucas, L., 2008, 'Transforming higher education in whose image? Exploring the concept of the 'world-class' university in Europe and Asia', Higher Education Policy, 21(3), pp. 83-97.

Deming, W.E., 1993, The New Economics (Cambridge, MA., MIT Press). 
Dill, D.D., 2011, 'Governing quality' in King, R., Marginson, S. \& Naidoo, R., (Eds.), 2011, Handbook on Globalisation and Higher Education, pp. 438-453 (Cheltenham, United Kingdom, Edward Elgar).

Eaton, J., 2011, 'U.S. accreditation: meeting the challenges of accountability and student achievement', Evaluation in Higher Education, 5(1), pp. 1-20.

European Association for Quality Assurance in Higher Education (ENQA), 2015, Standards and Guidelines for Quality Assurance in the European Higher Education Area (Helsinki, Finland).

Harvey, D., 2006, Spaces of Global Capitalism (New York, Verso).

Harvey, L., 1995, 'Editorial', Quality in Higher Education, 1(1), pp. 1-12.

Harvey, L., 2002, 'Evaluation for What?' Teaching in Higher Education, 7(3), pp. 245-63.

Harvey, L. \& Green, D., 1993, 'Defining quality', Assessment \& Evaluation in Higher Education, 18(1), pp. 9-34.

Harvey, L. \& Stensaker, B., 2008, 'Quality culture: understandings, boundaries, and linkages', European Journal of Education, 43 (4), pp. 427-42. Available at https://www.qualityresearchinternational.com/Harvey\%20papers/Harvey\%20and\%20Stensaker.p df (Accessed_25 May 2018).

Hou, A., 2012, 'Mutual recognition of quality assurance decisions on higher education institutions in three regions: a lesson for Asia', Higher Education, 64(6), pp. 911-26.

Hou, A., Chen, K., Hui-Jung \& Morse, R., 2014, 'Transforming the quality assurance framework for Taiwanese higher education: a glonacal context', Policy and Society, 33(3), pp. 275-85.

Iqbal, S., \& Harsh, O. K., 2013, 'A self-review and external review model for teaching and assessing novice programmers', International Journal of Information and Education Technology, 2(3), pp. 120-123.

Kabir, A.H., 2012, 'Neoliberal hegemony and the ideological transformation of higher education sector in Bangladesh', Critical Literacy: Theories and Practices Journal 6(2), pp. 2-15.

Koch, J.V. \& Fisher, J.L., 1998 Higher education and total quality management, Total Quality Management, 9, pp. 659-668.

Laughton, D., 2003, 'Why was the QAA approach to teaching quality assessments rejected by academics in UK HE? Assessment \& Evaluation in Higher Education 28(3), pp. 309-21.

Marginson, S. \& Rhoades, G., 2002, 'Beyond national states, markets, and systems of higher education: a glonacal agency heuristic’, Higher Education 43(3), pp. 281-309. 
Maringe, F., 2010, 'The meaning of globalization and internationalization in HE: findings from a world survey,' in Maringe F. and Foskett, N. (Eds.) 2010, Globalization and Internationalization in Higher Education: Theoretical, strategic, and management perspectives, pp. 17-34 (London, Bloomsbury).

Ministry of Education, Government of the People's Republic of Bangladesh, 2010, National Education Policy. Available at https://reliefweb.int/sites/reliefweb.int/files/resources/02. National-Education-Policy-2010-English.pdf (accessed 1 Feb 2020).

Ministry of Education, University Grants Commission of Bangladesh, 2015, , Institutional Quality Assurance Cell Operations Manual, second edition, (Dhaka, Higher Education Quality Enhancement Project and Quality Assurance Unit). Available at https://iqac.daffodilvarsity.edu.bd/images/pdf/IQAC-Operations-Manual_2nd-ed_2015.pdf (Accessed 6 February 2020).

Neave, G.,1997, 'On looking both ways at once: Scrutinies of the private life of higher education', European Review, 5(3), pp. 289-303. doi:10.1002/(SICI)1234981X(199707)5:33.0.CO;2-B

Newton, J., 2002, 'Views from below: academics coping with quality', Quality in Higher Education, 8(1), pp. 39-61.

Organisation for Economic Cooperation and Development (OECD) \& World Bank, 2007, Crossborder Tertiary Education: A way towards capacity development. (Paris, OECD Publishing).

Perry, P., 1991, 'Quality in higher education,' in Schuller, T. (Ed.), 1991, The Future of Higher Education, pp. 91-99 (Buckingham, SRHE/Open University Press).

The Quality Assurance Agency for Higher Education (QAA), 2012, UK Quality Code for Higher Education. Part B: Assuring and enhancing academic quality.

https://www.qaa.ac.uk/quality-code

Rahnuma, N., 2020, Evolution of quality culture in an HEI: critical insights from university staff in Bangladesh. Educational Assessment, Evaluation and Accountability. Available at https://doi.org/10.1007/s11092-019-09313-8(accessed 8 February 2020).

Ramsden, P., 2008, 'The future of higher education teaching and the student experience', Available at https://www.advance-he.ac.uk/knowledge-hub/future-higher-education-teachingand-student-experience(accessed 29 January 2020).

Razvi, S., Trevor-Roper, S., Goodliffe, T., Al-Habsi, F. \& Al-Rawahi, A., 2012, Evolution of OAAA strategic planning: using ADRI as an analytical tool to review its activities and strategic planning. Proceedings of Seventh Annual International Conference on Strategic Planning for 
Quality Assurance and Accreditation of Universities and Educational Arab Institutions, Cairo. Available at http://www.oaaa.gov.om/Conference/Cairo\%202012\%20Strategic\%20Planning\%20Paper\%20fin al.pdf (Accessed 3 February 2020)

Salmi, J., 2008, The Growing Accountability Agenda: Progress or mixed blessing? IMHE /OECD Annual Conference 'Outcomes of higher education: Quality relevance and impact' 8-10 September 2008, Paris, France. Available at http://www.oecd.org/dataoecd/3/30/41218034.pdf (accessed 25 May 2018).

Scott, G., 2003, 'Using an external quality audit as lever for institutional change', Assessment \& Evaluation in Higher Education, 28(3), pp. 323-32.

Shah, M. \& Jarzabkowski, L., 2013, 'The Australian higher education quality assurance framework', Perspectives: Policy and Practice in Higher Education, 17(3), pp. 96-106.

Sursock, A., 2012, 'Quality assurance and the European transformational agenda', in Curaj, A., Scott, P., Vlasceanu, L and Wilson, L. (Eds.), 2012, European Higher Education at the Crossroads: Between the Bologna Process and National Reforms, pp. 247-65 (Dordrecht, Springer).

The Tertiary Education Quality and Standards Agency (TEQSA), 2015, Higher Education Standards Framework (Threshold Standards) 2015. Available at https://www.legislation.gov.au/Details/F2015L01639

Trow, M., 2000, 'From Mass Higher Education to Universal Access: The American Advantage', Minerva 37, pp. 303-328.

United Nations Educational, Scientific and Cultural Organization (UNESCO), 2005, Guidelines for Quality Provision in Cross-Border Education (Paris: UNESCO Publishing).

United Nations Educational, Scientific and Cultural Organization (UNESCO) Institute of Statistics (UIS), 2018, Enrollment in Tertiary Education, Bangladesh. Available at http://data.uis.unesco.org/Index.aspx (accessed 25 May 2018).

World Bank, 2017, Bangladesh Higher Education Quality Enhancement Project (HEQEP) 15th Implementation Support Mission, Aide Memoire. Available at. http://pubdocs.worldbank.org/en/721581490608702587/AM-Mar-2017.pdf (accessed 29 July 2018). 
